\title{
IFNW1 wt Allele
}

National Cancer Institute

\section{Source}

National Cancer Institute. IFNW1 wt Allele. NCI Thesaurus. Code C52801.

Human IFNW1 wild-type allele is located in the vicinity of $9 p 22$ and is approximately $2 \mathrm{~kb}$ in length. This allele, which encodes interferon omega-1 protein, plays a role in intracellular signal transduction pathway progression in response to viral invasion. 